\title{
EFFECTS OF VARIOUS CARBON PRECURSORS COMBINATION IN REGULATING THE MOLAR FRACTION OF P(3HB-co-4HB) USING LOCALLY ISOLATED Cupriavidus sp. TMT11
}

\author{
JUN MENG CHAI, SHALINY HARI RAMA KRISHNAN, VINCENT TAN YEE HANG, \\ HANIS ATHIRAH MOHD HAMDAN, NURUL NADHIRAH RUZELAN and \\ SEVAKUMARAN VIGNESWARI* \\ Faculty of Science and Marine Environment, Universiti Malaysia Terengganu, \\ 21030 Kuala Nerus, Terengganu, Malaysia \\ ${ }^{*} E$-mail: vicky@umt.edu.my
}

Accepted 10 November 2020, Published online 25 December 2020

\begin{abstract}
The $\mathrm{P}(3 \mathrm{HB}-\mathrm{co}-4 \mathrm{HB})$ is commonly used for biomedical applications. This is due to the desired mechanical properties as well as biocompatibility, non-genotoxicity, and non-cytotoxicity of this copolymer. However, the production of $\mathrm{P}(3 \mathrm{HB}-\mathrm{co}-4 \mathrm{HB})$ with a specific $4 \mathrm{HB}$ molar fraction is still limited. In this study, carbon precursors at different combinations and concentration ratios have been used in the production of $\mathrm{P}(3 \mathrm{HB}-c o-4 \mathrm{HB})$ bioplastics using locally isolated Cupriavidus sp. TMT11. The carbon precursors 1,6-hexandiol, 1,4-butanediol, and $\gamma$-butyrolactone were used to screen for high cell biomass, PHA content, and 4HB molar fraction through Gas Chromatography (GC) analysis. Generally, the combination of various carbon precursors showed an increase in cell biomass. The carbon combination of 1,4-butanediol and $\gamma$-butyrolactone at the ratio of 4:2 and carbon combination of 1,6-hexanediol and $\gamma$-butyrolactone at a ratio of 1:5 showed high amount of cell biomass above 0.35 $\mathrm{g} / \mathrm{L}$ on day 3. Nevertheless, the $4 \mathrm{HB}$ molar fraction of both the combination was recorded as $9 \pm 0.27 \mathrm{~mol} \%$ and $14 \pm 1.1$ mol\% respectively. The lowest amount of cell biomass and PHA yield were recorded with the carbon combination of 1,6-hexanediol and 1,4-butanediol with the ratio 5:1 at 0.55 $\pm 0.13 \mathrm{~g} / \mathrm{L}$. However, the highest $4 \mathrm{HB}$ molar fraction of $89.37 \pm 3.6$ mol\% 4HB was recorded with this combination. The 4HB molar fraction above $80 \mathrm{~mol} \%$ was reported with a carbon combination of 1,6-hexanediol +1,4-butanediol at 5:1, 1:1, and 2:4 ratio. The varying combination of carbon precursors biosynthesized a wide range of $4 \mathrm{HB}$ molar fractions ranging from 9.07 to $89.37 \mathrm{~mol} \%$ 4HB.
\end{abstract}

Key words: Polyhydroxyalkanoate (PHA), bioplastics, $\mathrm{P}(3 \mathrm{HB}-\mathrm{co}-4 \mathrm{HB})$, carbon precursor

\section{INTRODUCTION}

Polyhydroxyalkanoate (PHA) is a family of microbial polymers produced intracellularly as carbon and energy storage material by a wide variety of bacteria under stress conditions. One of the unique characteristics of PHA is that it can be completely degraded in various environments and this garnered attention worldwide (Vigneswari et al., 2019).

Poly(3-hydroxybutyrate-co-4-hydroxybutyrate) $[\mathrm{P}(3 \mathrm{HB}-\mathrm{co}-4 \mathrm{HB})]$ copolymer is a member of the bacterial PHAs. P(3HB-co-4HB) has been found to have desirable mechanical properties for applications in the medical and pharmaceutical fields. The biosynthesis of $\mathrm{P}(3 \mathrm{HB}-c o-4 \mathrm{HB})$ involved the

\footnotetext{
* To whom correspondence should be addressed.
}

utilization of specific carbon precursors such as 1,4 butanediol, 1,6-hexanediol, $\gamma$-butyrolactone, 1,6hexanediol $\omega$-alkanediols with even number carbon atom numbers (Huong et al., 2018). P(3HB-co-4HB) was first produced by Cupriavidus necator, which is previously known as Ralstonia eutropha. There are many types of bacterial strains that accumulate $\mathrm{P}(3 \mathrm{HB}-\mathrm{co}-4 \mathrm{HB})$ such as Hydrogenophaga pseudoflava (Choi \& Lee, 1999), Comamonas acidovorans (Lee et al., 2004), and Alcaligenes latus (Lefebvre et al., 1997). The bacterial strain that has been used in this study is Cupriavidus sp. TMT11, a locally isolated from Teguh Megah Timur pond in Kuala Terengganu, Malaysia (Chai et al., 2017).

The production of $\mathrm{P}(3 \mathrm{HB}-c o-4 \mathrm{HB})$ with a wide range of 4HB molar faction is vital to tailor the various application of this copolymer. Effective approaches in biosynthesizing $\mathrm{P}(3 \mathrm{HB}-\mathrm{co}-4 \mathrm{HB})$ with 
varying $4 \mathrm{HB}$ molar fraction is necessary due to the increasing applications in medical and pharmaceutical sectors such as cardiovascular, orthopedic, drug delivery, and tissue engineering applications (Chee et al., 2008; Rahayu et al., 2008; Faezah et al., 2011). In this study, the three main carbon precursors namely 1,6-hexandiol, 1,4-butanediol, and $\gamma$-butyrolactone which are commonly used in the biosynthesis of $\mathrm{P}(3 \mathrm{HB}-\mathrm{co}-4 \mathrm{HB})$ are used to determine the effect the biomass of $\mathrm{P}(3 \mathrm{HB}-\mathrm{co}-4 \mathrm{HB})$ and the varying $4 \mathrm{HB}$ molar fraction using the locally isolated Cupriavidus sp. TMT11.

\section{MATERIALS AND METHODS}

\section{Bacterial strain and maintenance}

Cupriavidus sp. TMT 11 used in this study was isolated from Teguh Megah Timur pond in Kuala Terengganu, Malaysia as previously described (Meng et al., 2019). Briefly, it is maintained in $20 \%(\mathrm{v} / \mathrm{v})$ glycerol solution and stored at $-20^{\circ} \mathrm{C}$ for long term storage. The bacteria were revived in nutrient-rich (NR) broth for $24 \mathrm{hr}$ at $200 \mathrm{rpm}$ at $30^{\circ} \mathrm{C}$ (Huong et al., 2018).

\section{Biosynthesis of $\mathbf{P}(3 \mathrm{HB}-$ co- $4 \mathrm{HB})$ copolymer}

The production of the $\mathrm{P}(3 \mathrm{HB}-\mathrm{co}-4 \mathrm{HB})$ copolymer was carried out in a shake flask system. The inoculum was prepared with bacterial strain Cupriavidus sp. TMT11 was grown in nutrient broth containing $10 \mathrm{~g} / \mathrm{L}$ peptone, $10 \mathrm{~g} / \mathrm{L}$ meat extract, and $2 \mathrm{~g} / \mathrm{L}$ yeast extract at $30^{\circ} \mathrm{C}$ and placed in an orbital shaker for $15-18 \mathrm{hr}$ at $200 \mathrm{rpm}$. Later, 10\% (v/v) inoculum was transferred into the mineral medium to produce $\mathrm{P}(3 \mathrm{HB}-\mathrm{co}-4 \mathrm{HB})$ copolymer when the bacterial growth based on optical density measured using a spectrophotometer $(540 \mathrm{~nm})$ reaches 0.4-0.5. The mineral salt media (MSM) was prepared with $5.8 \mathrm{~g} / \mathrm{L} \mathrm{K}_{2} \mathrm{HPO}_{4}, 3.7 \mathrm{~g} / \mathrm{L} \mathrm{KH}_{2} \mathrm{PO}_{4}$ and $1.1 \mathrm{~g} / \mathrm{L}$ $\left(\mathrm{NH}_{4}\right)_{2} \mathrm{SO}_{4}$, trace elements $\left(2.78 \mathrm{~g} / \mathrm{L} \mathrm{FeSO}_{4} .7 \mathrm{H}_{2} \mathrm{O}\right.$, $1.98 \mathrm{~g} / \mathrm{L} \mathrm{MnCl}_{2} \cdot 4 \mathrm{H}_{2} \mathrm{O}$, and $2.81 \mathrm{~g} / \mathrm{L} \mathrm{CoSO} 4.7 \mathrm{H}_{2} \mathrm{O}$, $1.67 \mathrm{~g} / \mathrm{CaCl}_{2} .2 \mathrm{H}_{2} \mathrm{O}, 0.17 \mathrm{~g} / \mathrm{L} \mathrm{CuCl}_{2} .2 \mathrm{H}_{2} \mathrm{O}$ and 0.29 $\mathrm{g} / \mathrm{L} \mathrm{ZnSO}_{4} \cdot 7 \mathrm{H}_{2} . \mathrm{O}$ and $0.29 \mathrm{~g} \mathrm{ZnSO}_{4} .7 \mathrm{H}_{2} \mathrm{O}$ ) and $\mathrm{MgSO}_{4} \cdot 7 \mathrm{H}_{2} \mathrm{O}(0.1 \mathrm{M})$ which were sterilised at $121^{\circ} \mathrm{C}$ for $15 \mathrm{~min}$. The MSM was prepared in $50 \mathrm{~mL}$ in a $250 \mathrm{~mL}$ conical flask was added with a specific combination and concentration ratio of carbon precursor (Table 1). The MSM was then inoculated with inoculum grown in NR and incubated at $30^{\circ} \mathrm{C}$ in an orbital shaker at $150 \mathrm{rpm}$ for $72 \mathrm{hr}$. Bacterial growth will be monitored at intervals of $24 \mathrm{hr}$. The carbon sources used were 1,6-hexanediol, 1,4butanediol, and $\gamma$-butyrolactone with a total carbon concentration of $0.6 \mathrm{wt} \% \mathrm{C}$ but with a varying ratio as listed in Table 2.1. The cells were harvested by centrifugation (Centrifuge $5804 \mathrm{R}$ ) at $10000 \mathrm{rpm}$ for $15 \mathrm{~min}$. The cell pellet was subjected to lyophilization before further analysis (Norhafini et al., 2017).

\section{Analytical procedure}

The contents of $\mathrm{P}(3 \mathrm{HB}-c o-4 \mathrm{HB})$ and its composition which includes the $4 \mathrm{HB}$ molar fraction was obtained using gas chromatography (GC) analysis using Shimadzu GC-17A (Shimadzu, Japan) analysis (Braunegg et al., 1978) with Supelco SPBTM -1(L $\times$ I.D. $30 \mathrm{M} \times 0.25 \mathrm{~mm})$ [Sigma, USA] column (Amirul et al., 2009).

\section{Statistical analysis}

All experimental values are presented as means and standard deviation. The data were analyzed using ANOVA and Turkey's Test using SPSS 25 software. The $p \leq 0.05$ were considered significant.

\section{RESULTS AND DISCUSSION}

\section{Effect of different ratio of carbon precursors on bacterial growth}

Cupriavidus sp. TMT11 obtained from Teguh Megah Timur pond in Kuala Terengganu, Malaysia was cultivated using 1,6-hexanediol, 1,4-butanediol, and $\gamma$-butyrolactone with varying combinations and concentration ratio of carbon precursors. The effect of different ratios of carbon source in the biomass of $\mathrm{P}(3 \mathrm{HB}-\mathrm{co}-4 \mathrm{HB})$ production was observed at intervals of $24 \mathrm{hr}$ for a total of $72 \mathrm{hr}$. Figure 1 highlights the biomass of the cells at different time intervals. Based on the results obtained in Figure 1, the carbon combination of 1,4-butanediol and $\gamma$-butyrolactone at the ratio of $4: 2$ and carbon combination of 1,6-hexanediol and $\gamma$-butyrolactone at a ratio of 1:5 showed the highest amount of cell biomass above $0.35 \mathrm{~g} / \mathrm{L}$ on day 3 . The carbon combination of 1,6-hexanediol and 1,4-butanediol at a ratio of 5:1 recorded the lowest amount of cell biomass of $0.045 \pm 0.004 \mathrm{~g} / \mathrm{L}$ at day 3 of cultivation. The varying combination of carbon precursors using the mixed-substrate strategy of 1,4-butanediol and 1,6-hexanediol to regulate the molar fraction of

Table 1. Carbon concentration of carbon sources

\begin{tabular}{lc}
\hline Carbon sources & $\begin{array}{c}\text { Carbon } \\
\text { concentration } \\
\text { ratio }\end{array}$ \\
\hline 1,6-Hexanediol + 1,4-Butanediol & $5: 1$ \\
1,6-Hexanediol + $\gamma$-Butyrolactone & $1: 5$ \\
1,6-Hexanediol + $\gamma$-Butyrolactone & $4: 2$ \\
1,4-Butanediol + $\gamma$-Butyrolactone & $1: 5$ \\
1,4-Butanediol + $\gamma$-Butyrolactone & $4: 2$ \\
1,6-Hexanediol +1 1,4-Butanediol & $4: 2$ \\
1,6-Hexanediol +1 1,4-Butanediol & $1: 5$ \\
\hline
\end{tabular}


Table 2. Regulating the molar fraction of $\mathrm{P}(3 \mathrm{HB}-\mathrm{co}-4 \mathrm{HB})$ through combined carbon precursors using Cupriavidus sp. TMT11

\begin{tabular}{|c|c|c|c|c|c|}
\hline \multirow{2}{*}{ Carbon combination } & \multirow{2}{*}{$\begin{array}{c}\text { Carbon } \\
\text { concentration } \\
\text { ratio }\end{array}$} & \multirow{2}{*}{$\begin{array}{l}\text { PHA } \\
\text { content* } \\
\text { (wt\%) }\end{array}$} & \multicolumn{2}{|c|}{ PHA composition (mol\%) $)^{*}$} & \multirow{2}{*}{$\begin{array}{l}\text { PHA } \\
\text { yield } \\
(\mathrm{g} / \mathrm{L})^{*}\end{array}$} \\
\hline & & & $4 \mathrm{HB}$ & $3 \mathrm{HB}$ & \\
\hline 1,4-butanediol $+\gamma$-butyrolactone & $1: 5$ & $24.48 \pm 10.98^{a}$ & $33.87 \pm 6.37^{a}$ & $66.13 \pm 26.37^{a}$ & $0.36 \pm 0.14^{a}$ \\
\hline 1,4-butanediol $+\gamma$-butyrolactone & $4: 2$ & $51.09 \pm 12.69 \mathrm{bc}$ & $9.07 \pm 0.27^{b}$ & $90.93 \pm 0.27^{\mathrm{b}}$ & $4.70 \pm 1.70^{\mathrm{b}}$ \\
\hline 1,6-hexandiol $+\gamma$-butyrolactone & $1: 5$ & $54.82 \pm 10.33^{c}$ & $14.06 \pm 1.10^{c}$ & $85.94 \pm 14.10^{\mathrm{a}}$ & $4.89 \pm 0.74^{b}$ \\
\hline 1,6-hexandiol $+\gamma$-butyrolactone & $4: 2$ & $82.38 \pm 93.31^{c}$ & $20.10 \pm 9.78^{a}$ & $79.90 \pm 19.78^{a}$ & $3.54 \pm 4.05^{b}$ \\
\hline 1,6-hexanediol +1,4-butanediol & $1: 5$ & $44.62 \pm 14.25^{\mathrm{ab}}$ & $30.12 \pm 18.77^{a}$ & $69.88 \pm 18.77^{a}$ & $2.96 \pm 0.80^{c}$ \\
\hline 1,6-hexanediol +1,4-butanediol & $4: 2$ & $24.15 \pm 5.36^{\mathrm{ab}}$ & $23.77 \pm 3.07^{\mathrm{a}}$ & $76.23 \pm 3.07^{a}$ & $1.55 \pm 0.37^{\mathrm{ac}}$ \\
\hline 1,6-hexanediol +1,4-butanediol & $5: 1$ & $1.68 \pm 1.08^{d}$ & $89.37 \pm 3.60^{d}$ & $10.63 \pm 3.60^{c}$ & $0.55 \pm 0.13^{a}$ \\
\hline
\end{tabular}

Data show the mean \pm standard deviation of three replicates. Means with different alphabets $(a-d)$ within the same column are significantly different at $p \leq 0.05$ level (Tukey test).

* Data determined from GC analysis.

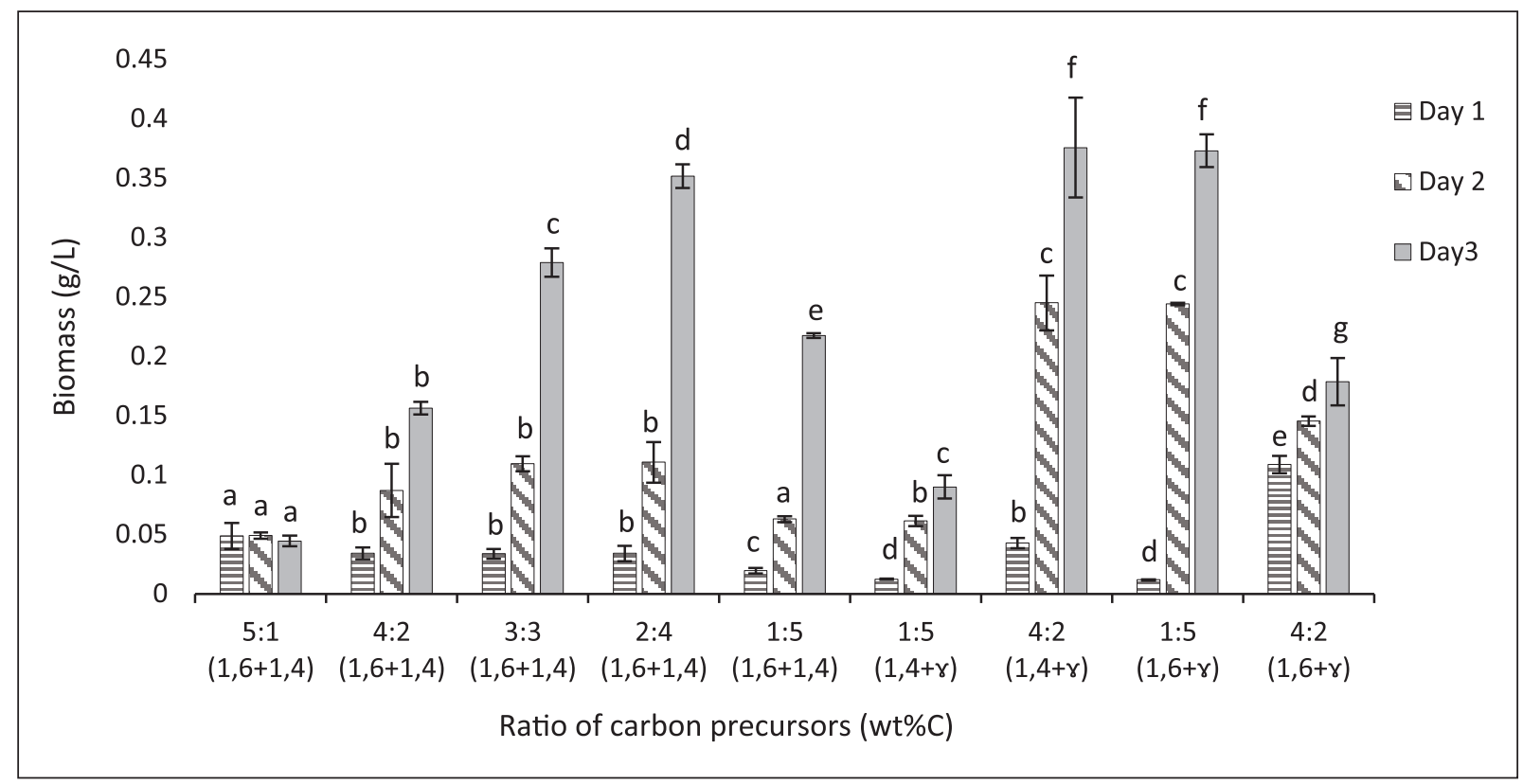

Fig. 1. Biomass of cells obtained at every $24 \mathrm{hr}$ time interval using different combinations and concentration ratio of carbon precursors. Means with different alphabets ( $\mathrm{a}-\mathrm{g}$ ) are significantly different at $p \leq 0.05$ level (Tukey test).

$\mathrm{P}(3 \mathrm{HB}-\mathrm{co}-4 \mathrm{HB})$ had been demonstrated by Huong et al. (2015) through their work. It was reported that the combination of carbon precursors showed a better increment of the bacteria biomass as compared to using sole carbon precursor. It was reported that the combination of more than one physiologically similar substrate provides increasing cell biomass, which can overcome the limitation faced by single-stage cultivation in biosynthesis (Syafiq et al., 2017). Furthermore, it was observed that as the concentration of 1,6-hexanediol decreases while 1,4-butanediol increases, the biomass of bacteria showed an increment. A similar trend was observed across different 1,6-hexanediol and 1,4-butanediol combination. A similar observation was also reported by Chanprateep et al. (2008), which stated that 1,4-butanediol is one of the effective carbon precursors for the increase in the 4HB molar fraction as compared to $\gamma$-butyrolactone. Biosynthesis of $\mathrm{P}(3 \mathrm{HB}-\mathrm{co}-4 \mathrm{HB})$ involves the conversion of 1,4butanediol to 4-hydroxybutyryl-CoA, before being converted to 4-hydroxybutyrate, where only a portion of 4-hydroxybutyrate will undergo a complex pathway to form 3-hydroxybutyrate (Steinbüchel \& Lütke-Eversloh, 2003; Iqbal \& Amirul, 2014; Norhafini et al., 2017). Hence, this further confirmed that the utilization of the optimum amount of 1,4-butanediol could greatly promote the production of $4 \mathrm{HB}$ monomer in copolymer $\mathrm{P}(3 \mathrm{HB}-\mathrm{co}-4 \mathrm{HB})$.

The percentage of increase in cell biomass between $24 \mathrm{hr}$ to $72 \mathrm{hr}$ was shown in Figure 2. It was reported that the carbon combination of 1,6-hexanediol and 1,4-butanediol at a ratio of $4: 2$ 


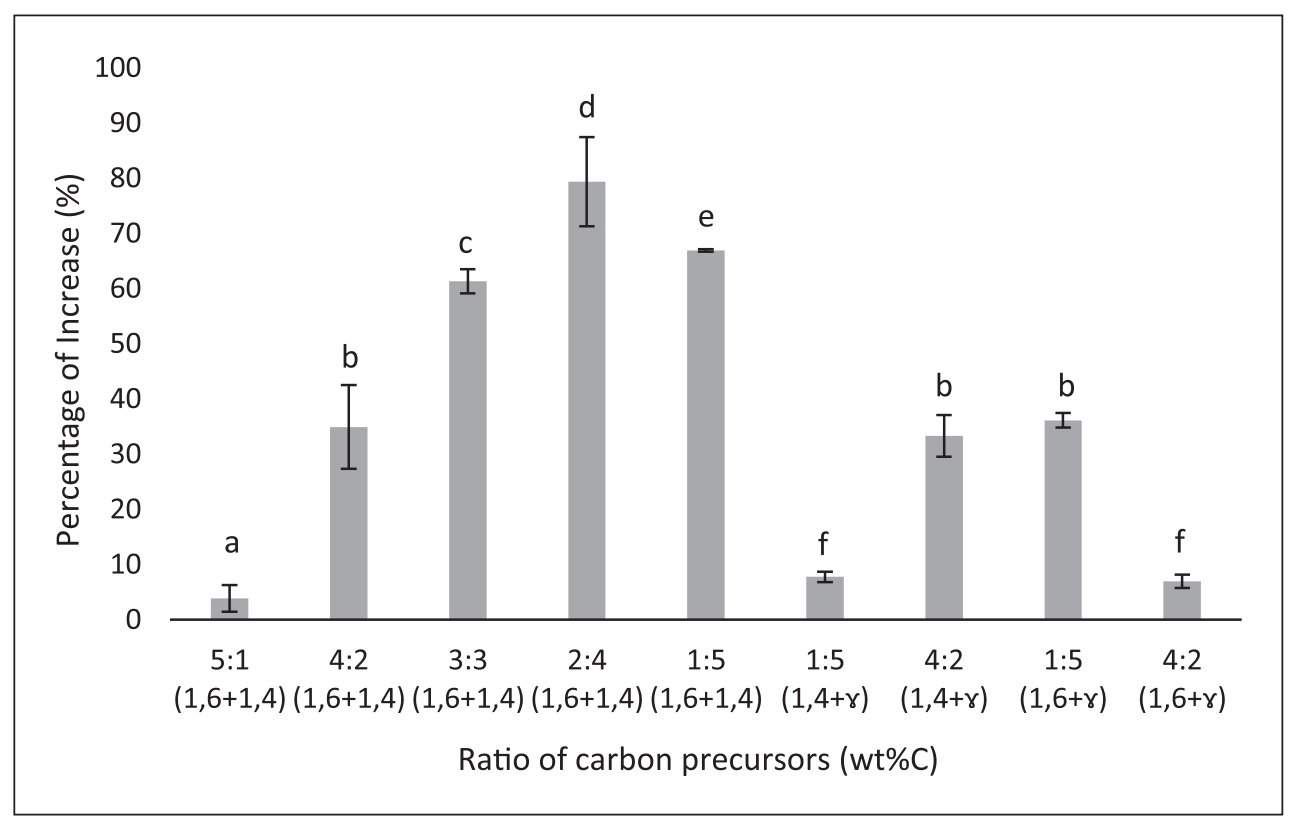

Fig. 2. Percentage of increase in cell biomass between time intervals. Means with different alphabets (a-f) are significantly different at $p \leq 0.05$ level (Tukey test).

reported the highest percentage of increment at $99.14 \%$. Whereas the carbon combination of 1,6hexanediol and $\alpha$-butyrolactone at $4: 2$ ratio has the lowest percentage of increment at $39.08 \%$. This could probably be attributed to the presence of 1,4-butanediol which further supports the fact that this carbon precursor 1,4-butanediol is one of the effective carbon precursors to not only increase the 4HB molar fraction but also cell biomass.

\section{Effect of mixed-substrates with a various concentration on copolymer $\mathrm{P}(3 \mathrm{HB}-\mathrm{co-}-4 \mathrm{HB})$ production}

The regulation of $4 \mathrm{HB}$ molar fraction of $\mathrm{P}(3 \mathrm{HB}-$ co-4HB) through combined carbon precursors using Cupriavidus sp. TMT11 was shown in Table 2. A high $4 \mathrm{HB}$ molar fraction of above $80 \mathrm{~mol} \%$ was recorded with a carbon combination of 1,6hexanediol +1,4-butanediol at the ratio of $5: 1,1: 1$, and 2:4. The highest PHA yield of the samples was observed with the carbon combination of 1,6hexanediol +1,4-butanediol at the ratio of $1: 1$ and $2: 4$. However, the carbon combination of $1,6-$ hexanediol $+\gamma$-butyrolactone at 1:5 ratio recorded the lowest PHA yield at $0.36 \mathrm{~g} / \mathrm{L}$. A similar observation was reported by Syafiq et al. (2017). The carbon precursors used during biosynthesis affect the composition of polymer produced by the bacterial cells. Generally, the carbon combination of 1,4-butanediol and $\alpha$-butyrolactoneat at the ratio of 1:5 has recorded relatively the lowest PHA yield. This could be because $\gamma$-butyrolactone could have been toxic to the bacterial cells (Steinbüchel \&
Lütke-Eversloh et al., 2003). Huong et al. (2015) reported that synergistic of 1,4-butanediol and 1,6hexanediol shows a better increment of the bacteria biomass as well as $4 \mathrm{HB}$ molar fraction as compared to using sole carbon precursor. This study was carried out to evaluate the bacterial growth as well as regulating the $4 \mathrm{HB}$ molar fraction by varying the carbon precursor. This indicates that the varying combination of carbon precursors used gave a wide range of $\mathrm{P}(3 \mathrm{HB}-\mathrm{co}-4 \mathrm{HB})$ ranging from 9.07 to 89.37 mol\% 4HB biosynthesized using Cupriavidus sp. TMT11.

\section{CONCLUSION}

The 4HB molar fractions of $\mathrm{P}$ (3HB-co-4HB) copolymer can be regulated using the combination of varying carbon precursor with a wide range of 4HB molar fraction exhibited. This work confirmed that the Cupriavidus sp. TMT11 has the highest bacterial biomass and highest 4HB mol\% accumulated when the combination of 1,6hexanediol and 1, 4-butanediol were used. This will enable the scale-up of $\mathrm{P}(3 \mathrm{HB}-\mathrm{co}-4 \mathrm{HB})$ copolymer production in a bioreactor to regulate the $4 \mathrm{HB}$ molar fractions. Carbon precursor concentration and combination based on ratio should be optimized to prevent the carbon precursors to become toxic to the bacteria, thus enhance the production of $\mathrm{P}(3 \mathrm{HB}-\mathrm{co}-4 \mathrm{HB})$. The biosynthesized $\mathrm{P}(3 \mathrm{HB}-\mathrm{co}-4 \mathrm{HB})$ copolymer can be potentially used for various biomedical applications in the future. 


\section{ACKNOWLEDGEMENTS}

The authors acknowledge the Ministry of Education Malaysia for supporting this work under the FRGS grant (FRGS/1/2017/STG05/UMT/03/1).

\section{REFERENCES}

Amirul, A.A., Yahya, A.R.M., Sudesh, K., Azizan, M.N.M. \& Majid, M.I.A. 2009. Isolation of poly(3-hydroxybutyrate-co-4-hydroxybutyrate) producer from Malaysian environment using $\gamma$ butyrolactone as carbon source. World Journal of Microbiology and Biotechnology, 25(7): 1199-1206.

Braunegg, G., Sonnleiter, B. \& Lafferty, R.M. 1978. A rapid gas chromatographic method for the determination of poly-3-hydroxybutyric acid in microbial biomass. European Journal of Applied Microbiology and Biotechnology, 6(1): 29-37.

Chanprateep, S., Katakura, Y., Visetkoop, S., Shimizu, H., Kulpreecha, S. \& Shioya, S. 2008. Characterization of new isolated Ralstoniaeutropha strain A-04 and kinetic study of biodegradable copolyester poly (3hydroxybutyrate-co-4-hydroxybutyrate) production. Journal of Industrial Microbiology \& Biotechnology, 35(11): 1205-1215.

Choi, J. \& Lee, S.Y.1999. Factors affecting the economics of polyhydroxyalkanoate production by bacterial fermentation. Applied Microbiology and Biotechnology, 51(1): 13-21.

Chee, J.W., Amirul, A.A., Tengku Muhammad, T.S., Majid, M.I.A. \& Mansor, S.M. 2008. The influence of copolymer ratio and drug loading level on the biocompatibility of $\mathrm{P}$ (3HB-co-4HB) synthesized by Cupriavidus sp. (USMAA2-4). Biochemical Engineering Journal, 38(3): 314-318.

Faezah, A.N., Rahayu, A., Vigneswari, S., Majid, M.I.A. \& Amirul, A.A. 2011. Regulating the molar fraction of 4-hydroxybutyrate in poly(3hydroxybutyrate-co-4-hydroxybutyrate) by biological fermentation and enzymatic degradation. World Journal of Microbiology and Biotechnology, 27(10): 2455-2459.

Huong, K.H., Elina, K.A.R. \& Amirul, A.A. 2018. Production of high molecular weight poly(3hydroxybutyrate-co-4-hydroxybutyrate) copolymer by Cupriavidus malaysiensis USMAA1020 utilising substrate with longer carbon chain. International Journal of Biological Macromolecules, 116: 217-223.
Huong, K.H., Kannusamy, S., Lim, S.Y.H. \& Amirul, A.A. 2015. Biosynthetic enhancement of single-stage poly (3-hydroxybutyrate-co-4hydroxybutyrate) production by manipulating the substrate mixtures. Journal of Industrial Microbiology \& Biotechnology, 42(9): 12911297.

Iszatty, I., Aidda, O.N., Hema, R. \& Amirul, A.A. 2017. Combination of 4-Hydroxybutyrate carbon precursors as substrate for simultaneous production of $\mathrm{P}(3 \mathrm{HB}-\mathrm{co}-4 \mathrm{HB})$ and yellow pigment by Cupriavidus sp. USMAHM13. Arabian Journal for Science and Engineering, 42(6): 2303-2311.

Iqbal, N. \& Amirul, A.A. 2014. Synthesis of P (3HBco4HB) copolymer with targetspecific $4 \mathrm{HB}$ molar fractions using combinations of carbon substrates. Journal of Chemical Technology \& Biotechnology, 89(3): 407-418.

Lee, S.Y. \& Choi, J. 1998. Effect of fermentation performance on the economics of poly(3hydroxybutyrate) production by Alcaligenes latus. Polymer Degradation and Stability, 59(3): 387-393.

Lee, W.H., Azizan, M.N.M. \& Sudesh, K. 2004. Effects of culture conditions on the composition poly(3-hydroxybutyrate-co-4-hydroxybutyrate) synthesized by Comamonas acidovorans. Polymer Degradation and Stability, 84(1): 129134.

Lefebvre, G., Rocher, M. \& Braunegg, G. 1997. Effects of low dissolved-oxygen concentrations on poly-(3-hydroxybutyrate-co-3hydroxybutyrate) production by Alcaligenes eutrophus. Applied and Environmental Microbiology, 63(3): 827-833.

Meng, C.J., Sadasivam, M. \& Vigneswari, S. 2019. Isolation and identification of $\mathrm{P}(3 \mathrm{HB}-\mathrm{co}-4 \mathrm{HB})$ producing bacteria from various locations in Kuala Terengganu. Malaysian Applied Biology Journal, 48(1): 199-206.

Norhafini, H., Thinagaran, L., Shantini, K., Huong, K., Syafiq, I.M., Bhubalan, K. \& Amirul, A.A. 2017. Synthesis of poly(3-hydroxybutyrate-co4-hydroxybutyrate) with high 4HB composition and PHA content using 1,4-butanediol and 1,6hexanediol for medical application. Journal of Polymer Research, 24(11): 189.

Rahayu, A., Zaleha, Z., Yahya, A.R.M., Majid, M.I.A. \& Amirul, A.A. 2008. Production of copolymer poly(3-hydroxybutyrate-co-4-hydroxybutyrate) through one-step cultivation process. World Journal of Microbiology and Biotechnology, 24(11): 2403-2409. 
Steinbüchel, A. \& Lütke-Eversloh, T. 2003. Metabolic engineering and pathway construction for biotechnological production of relevant polyhydroxyalkanoates in microorganisms. Biochemical Engineering Journal, 16(2): 81-96.

Syafiq, I.M., Huong, K.-H., Shantini, K., Vigneswari, S., Aziz, N.A., Amirul, A.A. \& Bhubalan, K. 2017. Synthesis of high 4-hydroxybutyrate copolymer by Cupriavidus sp. transformants using one-stage cultivation and mixed precursor substrates strategy. Enzyme and Microbial Technology, 98: 1-8.
Vigneswari, S., Rashid, N.S.B.T. \& Amirul, A.A. 2019. Biodegradation of polyhydroxyalkanoates (PHA) films in soil and lake environment. Malaysian Applied Biology, 48(1): 193-198. 